\title{
PERBEDAAN PENGETAHUAN GIZI PRAKONSEPSI DAN TINGKAT KONSUMSI ENERGI PROTEIN PADA WANITA USIA SUBUR (WUS) USIA 15-19 TAHUN KURANG ENERGI KRONIS (KEK) DAN TIDAK KEK DI SMA NEGERI 1 PASAWAHAN
}

\author{
Igna Nur'Arofah Umisah', Dyah Intan Puspitasari ${ }^{2}$ \\ ${ }^{1}$ Jl. Raya Babelan No. 63 Kebalen Kab. Bekasi 17610. \\ Email: ${ }^{1}$ igna21arofah@gmail.com \\ ${ }^{2}$ Program Studi Ilmu Gizi Fakultas Ilmu Kesehatan Universitas Muhammadiyah \\ Surakarta. J1. A. Yani, Pabelan, Kartasura, Surakarta. \\ Email:2 dyah.puspitasari@ums.ac.id
}

\begin{abstract}
ABSTRAK
Status gizi wanita usia subur (WUS) sering dikaitkan dengan persiapan menghadapi masa konsepsi atau prakonsepsi. Masalah KEK sering dikaitkan dengan pengetahuan gizi prakonsepsi. Tujuan penelitian ini adalah untuk mengetahui perbedaan pengetahuan gizi prakonsepsi dan tingkat konsumsi energi protein antara WUS usia 15-19 tahun KEK dan tidak KEK di SMA Negeri 1 Pasawahan. Penelitian ini menggunakan desain cross-sectional. Jumlah responden penelitian yaitu 37 responden KEK dan 37 tidak KEK, dengan teknik pengambilan sampel Proportional Stratified Random Sampling. Data KEK diambil dengan pengukuran Lingkar Lengan Atas (LILA), pengetahuan gizi prakonsepsi diperoleh menggunakan kuesioner dan data tingkat konsumsi energi protein diperoleh dengan formulir Semi Quantitative-Food Frequency Questionnaire (SQ-FFQ) 3 bulan terakhir. Uji kenormalan data menggunakan Kolmogorov Smirnov Test dan uji perbedaan menggunakan Independent T-Test dan uji MannWhitney. Sebanyak 54\% subjek memiliki pengetahuan gizi prakonsepsi yang kurang, tingkat konsumsi energi dengan kategori baik yaitu sebesar 52,7\% dan sebesar 56,8\% tingkat konsumsi protein kurang. Tidak ada perbedaan pengetahuan gizi prakonsepsi antara responden KEK dan tidak KEK di SMA Negeri 1 Pasawahan $(\mathrm{p}=0,179)$, ada perbedaan tingkat konsumsi energi $(\mathrm{p}=0,001)$ dan protein $(\mathrm{p}=0,001)$ antara responden KEK dan tidak KEK di SMA Negeri 1 Pasawahan.
\end{abstract}

Kata kunci: Kurang energi kronis, pengetahuan gizi prakonsepsi, tingkat konsumsi energi, tingkat konsumsi protein.

\begin{abstract}
The nutritional status of women of childbearing age (WCA) is often associated with preparing for a period of conception or preconception. Chronic Energy Insufficiency (CED) is often associated with preconception knowledge. The purpose of the research was to know the difference of preconception nutrition knowledge and proteinenergy consumption between WCA age 15-19 year with CED and notCED in SMA Negeri 1 Pasawahan. This study used cross-sectional
\end{abstract}


design. The number of respondents was 37 respondents with CED and 37 not-CED, with the proportional stratified random sampling. The CED data was obtained with Measurement Upper Arm Circumference (MUAC), preconception nutritional knowledge was obtained using questionnaire and protein-energy consumption level data was obtained with Semi Quantitative-Food Frequency Questionnaire (SQ-FFQ) form in the last 3 months. Normality test used the KolmogorovSmirnov and test of differences used Independent T-Test and MannWhitney.A 54\% preconception nutrition knowledge in less categorize, $52.7 \%$ energy consumption level in good categories and 56.8\% protein consumption level in less categorize. There was not a difference in preconception nutrition knowledge $(\mathrm{p}=0.179)$ between respondents CED and not-CED in SMA Negeri 1 Pasawahan, there was the difference of energy $(p=0.001)$ and protein $(p=0.001)$ consumption levels between respondents CED and not-CED in SMA Negeri 1 Pasawahan.

Keywords: Chronic energy deficiency, preconception nutrition knowledge, energy protein consumption level.

\section{PENDAHULUAN}

Masalah gizi di Indonesia pada umumnya masih didominasi oleh masalah gizi kurang. Masalah gizi kurang pada kelompok wanita mempengaruhi status gizi pada periode siklus kehidupan berikutnya (intergenation impact). Salah satu periode status gizi yang paling menentukan adalah status gizi pada masa pranikah atau yang biasa disebut masa prakonsepsi. Berdasarkan data Indikator Kesejahteraan Rakyat Tahun 2014, ratarata usia menikah wanita di Indonesia yaitu berkisar usia 19-24 tahun dengan presentase 43,95\%. Untuk Provinsi Jawa Barat sebanyak 46,19\% wanita di pedesaan menikah di usia 16-18 tahun (Departemen Gizi dan Kesehatan, 2011).

Menurut Cetin dkk. (2009), status gizi prakonsepsi merupakan salah satu faktor yang dapat mempengaruhi kondisi kehamilan dan kesejahteraan bayi. Keadaan kesehatan dan status gizi ibu hamil ditentukan jauh sebelumnya, yaitu pada masa remaja dan dewasa sebelum hamil atau selama menjadi Wanita Usia Subur (WUS). Status gizi dan kesehatan
WUS golongan remaja belum banyak diperhatikan, contohnya yaitu Kurang Energi Kronis (KEK). KEK dapat diketahui dengan cara pengukuran lingkar lengan atas (LILA) dengan ambang batas (cut off point) kurang dari 23,5 cm. Pengukuran mid-upper-arm circumference (MUAC) atau yang lebih dikenal dengan LILA dapat melihat perubahan secara paralel massa otot, sehingga bermanfaat untuk mendiagnosis kekurangan gizi (Gibson, 2005).

Secara nasional prevalensi KEK pada WUS dengan usia 15-49 tahun (tidak hamil) adalah 20,8\%. Prevalensi wanita tidak hamil kelompok usia 15-19 tahun mengalami peningkatan paling tinggi dibandingkan kelompok usia lainnya yaitu naik sebesar 15,7\%. Data Dinas Kesehatan pada tingkat Provinsi Jawa Barat tahun 2013 menunjukkan prevalensi WUS dengan KEK sebesar 21,6\% (Riskesdas, 2013).

KEK dapat memberikan dampak buruk bagi ibu dan janin. Kekurangan gizi pada ibu hamil dapat mempengaruhi proses pertumbuhan janin dan dapat menimbulkan keguguran, abortus, bayi 
lahir mati, kematian neonatal, cacat bawaan, anemia pada bayi, asfiksia intra partum (mati dalam kandungan) dan lahir dengan berat badan lahir rendah (BBLR). Efek jangka pendek KEK diantaranya yaitu anemia, perkembangan organ tidak optimal dan pertumbuhan fisik kurang, sehingga mengakibatkan kurang produktifnya seseorang. Sehingga perlu ada pencegahan terhadap kejadian KEK (Waryono, 2010).

Faktor-faktor yang dapat mempengaruhi kejadian KEK diantaranya terdapat faktor penyebab langsung dan tidak langsung. Faktor penyebab langsung yaitu tingkat konsumsi energi, tingkat konsumsi protein, penyakit infeksi dan usia menarche. Sedangkan faktor penyebab tidak langsung yaitu pengetahuan tentang gizi prakonsepsi dan aktifitas fisik (Achadi, 2013).

Menurut

Proctor

(2006), pengetahuan gizi prakonsespi merupakan faktor penting dalam mempersiapkan kehamilan. Ini bertujuan untuk mencegah terjadinya kekurangan asupan zat gizi selama kehamilan. Hasil penelitian Fauziyah (2014) di Kota Makassar menunjukkan bahwa wanita prakonsepsi yang berpengetahuan kurang memiliki peluang lebih besar untuk menderita KEK. Hasil uji statistik diperoleh bahwa responden dengan pengetahuan gizi baik memiliki pencegahan 0,06 kali terhadap KEK dibandingkan responden dengan pengetahuan gizi kurang $(\mathrm{p}=0,000,95 \%$ CI $=0,01-0,27)$. Hal ini sejalan dengan penelitian Simarmata (2008) bahwa ada hubungan signifikan antara pengetahuan gizi dengan KEK dengan besar risiko 3,852 yang artinya responden berpengetahuan gizi kurang memiliki peluang 3,852 kali menderita KEK dibandingkan responden berpengetahuan gizi baik ( $\mathrm{p}=0,009,95 \%$ $\mathrm{CI}=1,325-11,197)$.

KEK merupakan akibat seseorang menderita kekurangan zat gizi terutama energi dan protein yang berlangsung dalam jangka waktu lama atau menahun. Penelitian Sirajuddin (2010) di Sulawesi Selatan menunjukkan bahwa terdapat perbedaan asupan energi dan protein pada wanita yang KEK dan tidak KEK.

Data yang diambil bulan Juli 2016 oleh Puskesmas Pasawahan didapatkan sebanyak $40 \%$ ibu hamil mengalami KEK. Hasil survei pendahuluan pengukuran LILA dari total 217 siswi di SMA Negeri 1 Pasawahan, didapatkan $121(55,76 \%)$ siswi termasuk kategori KEK $(<23,5 \mathrm{~cm})$ dan $96(44,24 \%)$ siswi termasuk kategori tidak KEK $(\geq 23,5 \mathrm{~cm})$. Menurut Depkes (2003) tingkat besaran masalah risiko KEK yaitu <20\% (ringan), 20-30\% (sedang), dan $>30 \%$ (berat). Sehingga besaran masalah risiko di SMA Negeri 1 Pasawahan tergolong berat.

Berdasarkan uraian latar belakang di atas, penulis tertarik untuk melakukan penelitian tentang perbedaan pengetahuan gizi prakonsepsi dan tingkat konsumsi energi protein pada WUS usia 15-19 tahun dengan kejadian KEK dan tidak KEK di SMA Negeri 1 Pasawahan.

\section{METODE PENELITIAN}

Penelitian ini merupakan jenis penelitian observasional dengan rancangan cross-sectional yang dilaksanakan pada bulan Oktober 2016. Lokasi penelitian dilakukan di SMA Negeri 1 Pasawahan Kabupaten Kuningan Jawa Barat.

\section{Responden}

Populasi penelitian adalah wanita usia subur usia 15-19 tahun dengan jumlah 217 siswi. Jumlah responden sebanyak 74 yang terdiri dari 37 responden KEK dan 37 responden tidak KEK. Pengambilan responden menggunakan teknik proportional stratified random sampling. Kriteria Inklusi pada penelitian ini yaitu siswi 
SMA Negeri 1 Pasawahan, usia 15-19 tahun dan tidak sedang sakit sedangkan kriteria eksklusi pada penelitian ini yaitu sedang menjalankan diet dan vegetarian. Variabel dalam penelitian ini adalah pengetahuan gizi prakonsepsi dan tingkat konsumsi energi protein sebagai variabel bebas dan kejadian KEK pada wanita usia subur usia 15-19 tahun sebagai variabel terikat.

Teknik pengumpulan data kejadian KEK diperoleh dengan pengukuran LILA. Prosedur pengukuran dilakukan sesuai dengan Riskesdas 2007. Selanjutnya diklasifikasikan menggunakan rujukan dari Kemenkes RI Tahun 2002 yaitu responden dikatakan KEK jika LILA $<23,5 \mathrm{~cm}$. Pengambilan data primer pada penelitian ini dilakukan oleh 6 tenaga gizi teregistrasi. Data yang diambil diantaranya data pengukuran LILA dan tingkat konsumsi energi dan protein dengan metode wawancara menggunakan SQ-FFQ.

\section{Data pengetahuan gizi prakonsepsi}

Data pengetahuan gizi prakonsepsi diperoleh dengan mengisi kuesioner yang terdiri dari 20 soal pilihan ganda. Uji reliabilitas dengan nilai cronbach's alpha $0,823(>0,7)$ sehingga dapat dikatakan bahwa kuesioner pengetahuan gizi prakonsepsi reliabel. Dari 20 pertanyaan diperoleh setiap pertanyaan mempunyai nilai item total correlation $>0,3$. Skor tingkat pengetahuan gizi prakonsepsi dilakukan untuk mengetahui kemampuan kognitif sampel tentang manfaat, kebutuhan gizi dan dampak yang dialami jika kekurangan gizi prakonsepsi. Jika jawaban benar diberi nilai 1 dan jika salah diberi nilai 0 , kemudian diklasifikasikan berdasarkan Khomsan (2000) yaitu kategori baik jika responden dapat menjawab benar $\geq 80 \%$ pertanyaan.

\section{Data tingkat konsumsi energi dan protein}

Data tingkat konsumsi energi dan protein diperoleh dengan wawancara kepada responden tentang makanan yang dikonsumsi selama 3 bulan terakhir dengan metode Semi Quantitatif-Food Frequency Questionare (SQ-FFQ). Kuantitas tingkat konsumsi energi dan protein dirata-ratakan dalam sehari kemudian diinput ke dalam Nutrisurvey. Asupan rata-rata sehari kemudian dibandingkan dengan kebutuhan AKG 2013. Kebutuhan berdasarkan AKG diambil dengan cara membandingkan berat badan aktual dan berat badan anjuran kemudian dikalikan dengan anjuran kebutuhan energi dan protein dalam sehari. Tingkat konsumsi energi dan protein dikategorikan berdasarkan WNPG 2004 yaitu baik jika tingkat konsumsi energi dan protein berkisar $80 \%-110 \%$.

\section{Analisis data}

Analisa data dengan menggunakan program SPSS 21. Analisis univariat dilakukan dengan mendeskripsikan variabel bebas dan terikat yang digambarkan dengan membuat tabel distribusi frekuensi. Analisis bivariat dengan uji normalitas data menggunakan uji Kolmogorov Smirnov dan uji perbedaan tingkat konsumsi energi dan protein menggunakan uji Independent $T$ Test karena data berdistribusi normal dan uji perbedaan pengetahuan gizi prakonsepsi menggunakan uji MannWhitney karena data tidak berdistribusi normal. Penelitian ini telah mendapat persetujuan dari Komisi Etik Penelitian Kesehatan (KEKP) Fakultas Kedokteran Universitas Muhammadiyah Surakarta dengan nomor etichal clearance No. 357/B.1/KEPK-FKUMS/X/2016. 


\section{HASIL DAN PEMBAHASAN}

\section{Gambaran Umum SMAN 1 Pasawahan}

Jumlah seluruh siswa di SMA Negeri 1 Pasawahan yaitu 422 siswa yang terdiri dari 217 siswi perempuan dan 205 siswa laki-laki yang terbagi dalam 13 kelas. Lokasi SMA Negeri 1 Pasawahan berada di dataran tinggi gunung Ciremai dan didominasi oleh persawahan dan perbukitan. SMA Negeri 1 Pasawahan Memiliki 2 buah kantin dan 1 buah koperasi, yang menyediakan makanan berat (nasi), gorengan, makanan ringan (snack) dan minuman. Kegiatan kesehatan di SMA Negeri 1 Pasawahan berada di bawah pemantauan Puskesmas Pasawahan. Sarana pendidikan kesehatan seperti penyuluhan khususnya mengenai gizi belum pernah dilakukan di SMA Negeri 1 Pasawahan.

\section{Gambaran Umum Responden}

Responden dalam penelitian ini adalah siswi kelas X, XI dan XII di SMA Negeri 1 Pasawahan dengan kategori umur sebagai berikut:

Tabel 1. Distribusi Responden berdasarkan Kategori Umur

\begin{tabular}{ccccc}
\hline \multirow{2}{*}{ Usia } & \multicolumn{4}{c}{ Kategori KEK } \\
& \multicolumn{2}{c}{ KEK } & \multicolumn{2}{c}{ Tidak KEK } \\
\cline { 2 - 5 } & $\mathbf{N}$ & \% & $\mathbf{N}$ & \% \\
\hline 15 & 9 & 24,3 & 7 & 18,9 \\
16 & 10 & 27,0 & 13 & 35,1 \\
17 & 16 & 43,3 & 14 & 37,8 \\
18 & 2 & 5,4 & 3 & 8,1 \\
\hline Jumlah & 37 & 100 & 37 & 100 \\
\hline
\end{tabular}

Tabel 1 menunjukkan bahwa sebagian besar responden berumur 17 tahun yaitu sebanyak 30 responden, yang terdiri dari 16 responden KEK dan 14 responden tidak KEK. Pada usia 15-19 tahun, fisik seseorang terus berkembang diikuti dengan perkembangan aspek sosial maupun psikologisnya. Perubahan ini membuat seorang remaja perempuan banyak mencoba ragam gaya hidup, perilaku, tidak terkecuali pengalaman dalam menentukan makanan apa yang dikonsumsi yang sangat berpengaruh terhadap keadaan gizi seorang remaja. Namun perubahan ini tidak lepas dari faktor eksternal seperti status ekonomi dan akses pangan (Papalia dan Olds, 2001).

\section{Uji Univariat}

\section{Distribusi Responden Berdasarkan Tingkat Pengetahuan Gizi Prakonsepsi}

Pengetahuan responden diambil menggunakan kuesioner yang berisikan 20 butir soal. Responden diberikan waktu \pm 15 menit untuk mengisi kuesioner. Kategori pengetahuan dikatakan baik jika $\geq 80 \%$ dan kurang jika $<80 \%$. Data tingkat pengetahuan gizi prakonsepsi pada responden KEK dan tidak KEK yaitu sebagai berikut:

Tabel 2. Distribusi Responden berdasarkan Tingkat Pengetahuan Gizi Prakonsepsi

\begin{tabular}{ccccc}
\hline \multirow{2}{*}{$\begin{array}{c}\text { Kategori } \\
\text { Pengetahuan }\end{array}$} & \multicolumn{3}{c}{ KEK } & \multicolumn{2}{c}{ Tidak KEK } \\
\cline { 2 - 5 } & $\mathbf{N}$ & $\boldsymbol{\%}$ & $\mathbf{N}$ & \% \\
\hline Kurang & 24 & 64,9 & 16 & 43,2 \\
Baik & 13 & 35,1 & 21 & 56,8 \\
\hline Jumlah & 37 & 100 & 37 & 100 \\
\hline
\end{tabular}

Tabel 2 menunjukkan bahwa sebagian besar responden memiliki pengetahuan gizi prakonsepsi yang kurang yaitu sebanyak 40 responden, yang terdiri dari 24 responden KEK dan 16 responden tidak KEK. Item pertanyaan yang sulit dijawab responden yaitu mengenai konsep gizi dasar dan dampak kekurangan zat besi. Pertanyaan tersebut sulit dijawab karena responden mengaku belum pernah mengetahui tentang gizi. Hal ini dikarenakan responden tidak pernah mendapatkan materi penyuluhan mengenai gizi. Distribusi statistik deskriptif berdasarkan tingkat 
pengetahuan gizi prakonsepsi dapat dilihat pada Tabel 3.

Tabel 3. Distribusi Statistik Deskriptif berdasarkan Tingkat Pengetahuan Gizi Prakonsepsi

\begin{tabular}{ccc}
\hline Uji Statistik & \multicolumn{2}{c}{ Kategori } \\
& KEK & Tidak KEK \\
\hline Mean & 75,90 & 77,50 \\
Median & 75 & 80 \\
Standar Deviasi & 7,15 & 11,41 \\
Minimum & 60 & 45 \\
Maksimum & 95 & 95 \\
\hline
\end{tabular}

Rata-rata nilai sampel KEK yaitu $75,9 \pm 7,15$ sedangkan pada sampel tidak KEK yaitu 77,56 $\pm 11,41$. Nilai minimum pada sampel KEK yaitu 60 sedangkan sampel tidak KEK yaitu 45. Skor maksimum pada sampel KEK dan tidak KEK yaitu 95. Berdasarkan hasil penelitian, responden KEK lebih banyak mempunyai pengetahuan yang kurang dibandingkan responden tidak KEK.

Pengetahuan merupakan faktor yang sangat berpengaruh terhadap pengambilan keputusan. Beberapa hasil penelitian menunjukkan bahwa tingkat pengetahuan gizi yang baik secara konsisten terwujud menjadi perilaku pemilihan konsumsi makanan. Tujuan pemilihan konsumsi makanan yang didasari oleh pengetahuan gizi yang baik yaitu untuk mencapai status gizi yang optimal (Adhiyati, 2013).

Pengetahuan tentang gizi adalah apa yang diketahui tentang makanan meliputi makanan sehat, makanan sehat untuk golongan usia tertentu (misalnya wanita usia subur prakonsepsi), dan cara memilih, mengolah dan meyiapkan makanan yang benar. Wanita usia subur yang memiliki pengetahuan gizi yang baik akan mampu memilih jenis makanan yang tepat untuk dirinya baik dari segi kuantitas maupun kualitas yang dikonsumsinya. Dengan demikian pengetahuan gizi merupakan salah satu faktor protektif dalam mempersiapkan kehamilan atau prakonsepsi (Khomsan, 2000).
Gizi prakonsepsi merupakan suatu cara untuk memperhatikan status gizi calon pengantin demi tercapainya keluarga yang sehat dan keturunan yang berkualitas. Untuk mempersiapkan keturunan yang berkualitas diperlukan perencanaan dan penanganan terhadap semua aspek terutama kesehatan dan status gizi wanita usia subur sedini mungkin (Gardiner, 2008).

\section{Distribusi Responden Berdasarkan Tingkat Konsumsi Energi dan Protein}

Data tingkat konsumsi energi dalam penelitian ini diambil menggunakan metode Semi Quantitative Food Frequency. Data diambil dengan cara menanyakan makanan dan minuman yang telah dikonsumsi selama 3 bulan terakhir, kemudian dikonversikan menjadi asupan energi rata-rata perhari dalam bentuk satuan kalori. Selanjutnya, hasil Semi Quantitative Food Frequency diolah menggunakan program Nutrisurvey, lalu dibandingkan dengan AKG Individu. AKG individu didapat dengan melakukan koreksi terhadap berat badan aktual dengan berat badan standar pada tabel AKG 2013. Kategori tingkat konsumsi energi dikatakan kurang jika asupan $<80 \%$, baik jika 80-110\%, lebih jika $>110 \%$.

Data tingkat konsumsi energi pada responden KEK dan tidak KEK yaitu dapat dilihat pada Gambar 1.

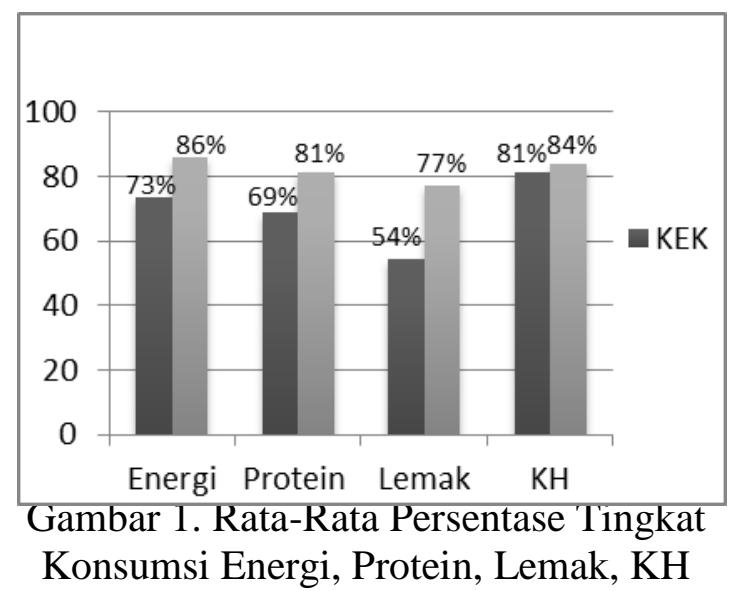


Rata-rata persentase konsumsi energi, protein, lemak dan karbohidrat pada responden tidak KEK lebih tinggi dibandingkan responden KEK. Rata-rata untuk persentase konsumsi pada responden tidak KEK yaitu energi (86\%), protein $(81 \%)$, lemak $(77 \%)$ dan karbohidrat (84\%). Berikut adalah tabel rata-rata asupan energi, protein, lemak dan karbohidrat dalam waktu 3 bulan:

Tabel 4. Rata-Rata Asupan Energi, Protein, Lemak, Karbohidrat per-Hari

\begin{tabular}{ccccc}
\hline Kategori & $\begin{array}{c}\text { Energi } \\
\text { (Kkal) }\end{array}$ & $\begin{array}{c}\text { Protein } \\
\text { (gr) }\end{array}$ & $\begin{array}{c}\text { Lemak } \\
\text { (gr) }\end{array}$ & $\begin{array}{c}\text { KH } \\
\text { (gr) }\end{array}$ \\
\hline KEK & 1238 & 33,8 & 54 & 201 \\
Tidak & 1908 & 51,8 & 68 & 252 \\
KEK & & & & \\
AKG & 2125 & $59-69$ & 71 & 292 \\
2013 & & & & \\
\hline
\end{tabular}

Dari Tabel 4 dapat dilihat bahwa rata-rata asupan energi sehari pada responden KEK yaitu 1238 kkal sedangkan pada responden tidak KEK yaitu 1908 kkal. Rata-rata asupan protein responden KEK yaitu 33,8 gram sedangkan pada responden tidak KEK yaitu 51,8 gram. Distribusi statistik deskriptif berdasarkan tingkat konsumsi energi dapat dilihat pada Tabel 5.

Tabel 5. Distribusi Statistik Deskriptif berdasarkan Tingkat Konsumsi Energi

\begin{tabular}{ccc}
\hline Uji Statistik & \multicolumn{2}{c}{ Kategori } \\
& KEK & Tidak KEK \\
\hline Mean & 73,36 & 85,85 \\
Median & 75,90 & 85,90 \\
Standar Deviasi & 10,60 & 9,03 \\
Minimum & 45,30 & 64,50 \\
Maksimum & 90,90 & 111,50 \\
\hline
\end{tabular}

Rata-rata persentase tigkat konsumsi energi sampel KEK yaitu $73,36 \% \pm 10,6 \%$ sedangkan pada sampel tidak KEK $85,85 \% \pm 9,03 \%$. Nilai minimum persentase tingkat konsumsi energi pada sampel KEK yaitu 45,3\% sedangkan sampel tidak KEK yaitu $64,5 \%$. Persentase maksimum tingkat konsumsi energi pada sampel KEK yaitu 90,9\% sedangkan pada sampel tidak KEK yaitu $111,5 \%$.

Energi dalam tubuh manusia dapat timbul dikarenakan adanya pembakaran karbohidrat, protein, lemak. Untuk mencukupi kebutuhan energi diperlukan asupan zat-zat gizi yang cukup. Prinsipprinsip ilmu gizi, seseorang tidak dapat terus menerus menggunakan cadangan energi dalam tubuh. Jika dilakukan secara terus menerus akan mengakibatkan keadaan kurang gizi yang dapat mengakibatkan KEK (Kartasapoetra, 2005).

Jika kebutuhan energi tidak terpenuhi selama jangka waktu yang lama, WUS akan mengalami KEK. Ibu dengan KEK akan berisiko mengandung janin yang kurang gizi sehingga mengakibatkan gangguan pertumbuhan janin dan mengakibatkan bayi berat badan lahir rendah (Hadi, 2005).

Hasil penelitian Marlenywati (2010), wanita yang mempunyai tingkat konsumsi energi $<80 \%$ AKG mempunyai peluang terjadinya KEK 12,031 kali dibandingkan wanita dengan tingkat konsumsi energi $>80 \% \quad(\mathrm{p}=0,001,95 \%$ $\mathrm{CI}=3,727-38,84)$. Peluang wanita dengan tingkat konsumsi protein $<80 \% \quad \mathrm{AKG}$ mempunyai peluang terjadinya KEK 13,416 kali dibandingkan wanita dengan tingkat konsumsi protein $>80 \%$ ( $\mathrm{p}=0,001$, 95\% CI =4,127-41,01).

Menurut UNICEF, faktor-faktor yang mempengaruhi tingkat konsumsi energi dan protein antara lain pendidikan yang mempengaruhi pengetahuan, pengetahuan yang mempengaruhi kesehatan, pendapatan dan besar keluarga yang mempengaruhi daya beli dan pemilihan makanan, serta ketersediaan bahan makananan rumah tangga. Faktorfaktor tersebut saling berkaitan dalam mempengaruhi tingkat konsumsi energi dan protein seseorang (Soekirman, 1999). 
Distribusi Responden Berdasarkan Tingkat Konsumsi Protein

Tingkat konsumsi protein responden dalam penelitian ini diambil menggunakan metode Semi Quantitative Food Frequency. Data diambil dengan cara menanyakan makanan dan minuman yang telah dikonsumsi selama 3 bulan terakhir, kemudian dikonversikan menjadi asupan protein rata-rata perhari dalam bentuk satuan gram. Selanjutnya, hasil Semi Quantitative Food Frequency diolah menggunakan program NutriSurvey, lalu dibandingkan dengan AKG Individu. AKG individu didapat dengan melakukan koreksi terhadap berat badan aktual dengan berat badan standar pada tabel AKG 2013. Kategori asupan protein dikatakan kurang jika asupan $<80 \%$, baik jika $80-110 \%$, lebih jika $>110 \%$. Data tingkat konsumsi protein sampel KEK dan tidak KEK yaitu sebagai berikut:

Tabel 6. Distribusi Sampel berdasarkan Tingkat Konsumsi Protein

\begin{tabular}{ccccc}
\hline Kategori & \multicolumn{4}{c}{ Kategori KEK } \\
\cline { 2 - 5 } Tingkat & \multicolumn{2}{c}{ KEK } & \multicolumn{3}{c}{ Tidak KEK } \\
\cline { 2 - 5 } Konsumsi & $\mathbf{N}$ & $\mathbf{\%}$ & $\mathbf{N}$ & $\mathbf{\%}$ \\
\hline Kurang & 33 & 89,2 & 9 & 24,3 \\
Baik & 4 & 10,8 & 28 & 75,7 \\
Lebih & 0 & 0 & 0 & 0 \\
\hline Jumlah & 37 & 100 & 37 & 100 \\
\hline Tabel & 6 & menunjukkan & bahwa
\end{tabular}

sebagian besar sampel memiliki tingkat konsumsi protein yang kurang yaitu sebanyak 42 sampel, yang terdiri dari 33 sampel KEK dan 9 sampel tidak KEK. Distribusi statistik deskriptif berdasarkan tingkat konsumsi protein dapat dilihat pada Tabel 7.

Tabel 7. Distribusi Statistik Deskriptif Berdasarkan Tingkat Konsumsi Protein

\begin{tabular}{ccc}
\hline Uji Statistik & \multicolumn{2}{c}{ Kategori } \\
& KEK & Tidak KEK \\
\hline Mean & 69,04 & 81,35 \\
Median & 70,70 & 82,02 \\
Standar Deviasi & 9,80 & 10,20 \\
Minimum & 44,10 & 59,90 \\
Maksimum & 84 & 108,9 \\
\hline
\end{tabular}

Rata-rata persentase tingkat konsumsi protein sampel KEK yaitu $69,04 \% \pm 9,8 \%$ sedangkan pada sampel tidak KEK $81,35 \% \pm 10,21 \%$. Nilai minimum persentase tingkat konsumsi protein pada sampel KEK yaitu 44,1\% sedangkan sampel tidak KEK yaitu $59,9 \%$. Persentase maksimum tingkat konsumsi energi pada sampel KEK yaitu $84 \%$ sedangkan pada sampel tidak KEK yaitu $10,8,9 \%$.

Peran protein dalam membangun struktur jaringan tubuh menjadi bagian akhir untuk menyuplai kebutuhan energi pada saat asupan karbohidrat dan lemak tidak cukup. Asupan lemak dan karbohidrat sebagai pembanding asupan protein dalam perannya sebagai sumber energi alternatif (Irianto, 2014).

Salah satu faktor penyebab KEK adalah konsumsi makan yang tidak cukup mengandung energi dan protein. Kekurangan asupan energi akan mempengaruhi kebutuhan protein. Protein merupakan energi alternatif terakhir setelah karrbohidrat dan lemak yang digunakan jika tubuh tidak memperoleh asupan energi yang cukup. Pemecahan protein pada akhirnya akan menyebabkan deplesi massa otot, karena salah satu fungsi protein adalah untuk pertumbuhan dan pemeliharaan sel-sel (Almatsier, 2003).

Protein yang cukup berkaitan dengan gizi normal yaitu memperkecil faktor risiko terjadinya KEK yang berhubungan dengan hasil pengukuran LILA. Kolagen adalah protein utama dalam tendon dan ligamen dan juga bahan interseluler yang mengikat bersama sel. Fibrin dan miosin adalah protein yang ditemukan dalam otot. Terkait dengan tingkat kecukupan konsumsi protein maka protein akan berfungsi sebagai energi alternatif (Guyton dan Hall, 2008). 


\section{Uji Bivariat}

\section{Perbedaan \\ Pengetahuan \\ Gizi \\ Prakonsepsi antara Responden KEK dan tidak KEK}

Pengetahuan responden diambil menggunakan kuesioner yang berisikan 20 butir soal. Responden diberikan waktu \pm 15 menit untuk mengisi kuesioner pengetahuan gizi prakonsespi. Berdasarkan hasil uji normalitas data didapatkan hasil $\mathrm{p}=0,014$ yang artinya bahwa data tidak berdistribusi normal $(<0,05)$. Karena data tidak berdistribusi normal, maka dilanjutkan dengan uji Mann-Whitney untuk mengetahui perbedaan pengetahuan gizi prakonsepsi antara responden KEK dan tidak KEK. Berikut adalah hasil mengenai uji perbedaan pengetahuan gizi prakonsepsi pada responden KEK dan tidak KEK:

Tabel 8. Analisis Uji Perbedaan Tingkat Pengetahuan Gizi Prakonsepsi

\begin{tabular}{cccc}
\hline \multirow{2}{*}{ Uji Statistik } & \multicolumn{2}{c}{ Kategori } & \\
& KEK & Tidak & P \\
KEK & \\
\hline Mean & 75,95 & 77,56 & \\
Median & 75 & 80 & \\
Standar Deviasi & 7,15 & 11,41 & 0,179 \\
Minimum & 60 & 45 & \\
Maksimum & 95 & 95 & \\
\hline * Uji Mann-Whitney & &
\end{tabular}

Nilai rata-rata pengetahuan gizi prakonsespi pada responden KEK yaitu 75,95 sedangkan responden tidak KEK yaitu 77,56 sehingga termasuk dalam kategori pengetahuan kurang. Berdasarkan uji Mann-Whitney didapatkan hasil $\mathrm{p}=$ 0,179 ( $>>0,05)$ maka H0 diterima sehingga dapat disimpulkan tidak ada perbedaan pengetahuan gizi prakonsepsi antara responden KEK dan tidak KEK di SMA Negeri 1 Pasawahan. Memiliki pengetahuan yang tinggi tentang gizi prakonsepsi tanpa disertai dengan perubahan perilaku dalam kehidupan sehari-hari merupakan faktor penyebab tidak ada adanya perbedaan pengetahuan gizi parkonsepsi di SMA Negeri 1 Pasawahan.

Santosa (2013) menyatakan bahwa pengetahuan yang baik belum tentu terwujud dalam suatu tindakan yang nyata. Mewujudkan pengetahuan menjadi perilaku nyata dipengaruhi oleh faktor lain diantaranya ketersediaan sarana, fasilitas dan kemampuan untuk memenuhi segala kebutuhan dalam perilaku pencegahan. Selain itu, dibutuhkan juga adanya dukungan dari keluarga. Pengetahuan baik yang dimiliki oleh responden masih dalam tingkatan tahu dan belum diaplikasikan dalam perilaku yang nyata.

Pengetahuan gizi prakonsepsi merupakan faktor tidak langsung yang mempengaruhi kejadian KEK. Pengetahuan tentang bahan makanan akan mempengaruhi perilaku dalam pemilihan dan pengolahan makanan. Namun, pengaruh pengetahuan gizi terhadap konsumsi makanan tidak selalu linier, artinya semakin tinggi tingkat pengetahuan gizi, belum tentu konsumsi makanan menjadi baik. Konsumsi makanan jarang terpenuhi oleh pengetahuan gizi sendiri tetapi merupakan interaksi sikap dan keterampilan dalam konsumsi makanan (Khomsan, 2000).

Gizi prakonsepsi didefinisikan sebagai masukan makanan dan kebiasaan makan yang dilakukan wanita usia subur yang merencanakan kehamilan. Pengetahuan gizi prakonsepsi berperan penting dalam menyiapkan kehamilan yang sehat. Penelitian tentang gizi telah menunjukan adanya hubungan yang positif antara pengetahuan dan status gizi prakonsepsi dengan kondisi kehamilan dengan kesehatan bayi yang dilahirkan (Weerd, 2003). 


\section{Perbedaan Tingkat Konsumsi Energi antara Responden KEK dan tidak KEK}

Tingkat konsumsi energi responden dalam penelitian ini diambil menggunakan metode Semi Quantitative Food Frequency dalam 3 bulan terakhir. Berdasarkan hasil uji normalitas data didapatkan hasil $\mathrm{p}=0,400$ yang artinya bahwa data berdistribusi normal. Karena data berdistribusi normal, maka dilanjutkan dengan uji Independent T-Test untuk mengetahui perbedaan tingkat konsumsi energi antara responden KEK dan tidak KEK. Berikut adalah hasil uji perbedaan tingkat konsumsi energi pada responden KEK dan tidak KEK:

Tabel 9. Analisis Uji Perbedaan Tingkat Konsumsi Energi

\begin{tabular}{cccc}
\hline \multirow{2}{*}{ Uji Statistik } & \multicolumn{2}{c}{ Kategori } & \\
& KEK & $\begin{array}{c}\text { Tidak } \\
\text { KEK }\end{array}$ & p \\
\hline Mean & 73,36 & 85,85 & \\
Median & 75,9 & 85,9 & \\
Standar Deviasi & 10,6 & 9,03 & $0,001^{*}$ \\
Minimum & 45,3 & 64,5 & \\
Maksimum & 90,9 & 111,5 & \\
\hline
\end{tabular}

* Uji Independent T-Test

Nilai rata-rata tingkat konsumsi energi pada responden KEK yaitu 73,36\% sehingga termasuk kategori kurang sedangkan responden tidak KEK masuk kategori baik dengan rata-rata $85,85 \%$. Berdasarkan uji Independent T-Test didapatkan hasil $\mathrm{p}=0,001(\mathrm{p}<0,05)$ yang artinya ada perbedaan tingkat konsumsi energi pada responden KEK dan tidak KEK di SMA Negeri 1 Pasawahan. Penelitian Petrika (2014) menunjukkan adanya perbedaan tingkat konsumsi energi antara kelompok KEK dan tidak KEK di Kecamatan Sedayu, Bantul. Penelitian Marlenywati (2010) pada remaja 15-19 tahun di Kota Pontianak menunjukkan bahwa konsumsi energi $<80 \%$ berpeluang mengalami KEK 8,051 kali dibandingkan dengan konsumsi energi $\geq 80 \% \quad(\mathrm{p}=0,001$, 95\% CI =3,727-38,84).

Manusia harus memproses hasil penyerapan produk-produk pencernaan karbohidrat, lipid dan protein dari makanan. Secara berurutan, produkproduk ini terutama adalah glukosa, asam lemak serta gliserol dan asam amino. Semua produk hasil pencernaan diproses melalui lintasan metaboliknya masingmasing menjadi suatu produk umum yaitu Asetil KoA, yang kemudian akan dioksidasi secara sempurna melalui siklus asam sitrat. Dalam tahap ini dihasilkan energi berupa ATP. Jika sumber glukosa berlebihan maka akan diubah menjadi polimer glukosa (disebut glikogen). Jika terjadi kekurangan glukosa, maka glikogen dipecah menjadi glukosa. Selanjutnya glukosa mengalami glikolisis, diikuti dengan oksidasi piruvat sampai dengan siklus asam sitrat. Ketika glukosa cadangan glikogen habis, maka sumber energi non karbohidrat yaitu lipid dan protein harus digunakan. Jalur ini dinamakan glukoneogenesis (pembentukan glukosa baru) karena dianggap lipid dan protein harus diubah menjadi glukosa baru yang selanjutnya mengalami katabolisme untuk memperoleh energi. Jika keadaan ini terus berlanjut maka lemak dan protein akan digunakan secara terus menerus sebagai cadangan energi alternatif (Murray, 2000).

Manusia membutuhkan energi untuk mempertahankan hidup, menunjang pertumbuhan dan melakukan aktivitas fisik. Konsumsi energi diperoleh dari bahan makanan yang mengandung karbohidrat, lemak dan protein. Energi dalam tubuh manusia dapat timbul karena adanya pembakaran karbohidrat, protein, dan lemak sehingga manusia membutuhkan zat-zat makanan yang cukup untuk memenuhi kecukupan energinya. Tingkat kecukupan energi ini akan mempengaruhi status gizi (Budiyono, 2002). 
Tingkat konsumsi energi merupakan penyebab langsung terjadinya KEK. KEK adalah keadaan dimana seseorang mengalami kekurangan gizi (energi dan protein) yang berlangsung lama atau menahun dengan LILA kurang dari 23,5 $\mathrm{cm}$. Kurangnya konsumsi energi dapat menyebabkan tubuh mengalami keseimbangan energi negatif, sehingga dapat menurunkan berat badan dan mempengaruhi ukuran LILA seseorang. Asupan energi yang terpenuhi dapat memperkecil resiko terjadinya KEK (Bisai, 2008).

Perbedaan Tingkat Konsumsi Protein antara Responden KEK dan tidak KEK

Tingkat konsumsi protein responden dalam penelitian ini diambil menggunakan metode Semi Quantitative Food Frequency dalam 3 bulan terakhir. Berdasarkan hasil uji normalitas data didaptkan hasil $\mathrm{p}=0,475$ yang artinya bahwa data berdistribusi normal ( $p>0,05)$. Karena data berdistribusi normal, maka dilanjutkan dengan uji Independent T-Test untuk mengetahui perbedaan tingkat konsumsi protein antara responden KEK dan tidak KEK. Berikut adalah hasil mengenai uji perbedaan tingkat konsumsi protein pada responden KEK dan tidak KEK:

Tabel 10. Analisa Uji Perbedaan Tingkat Konsumsi Protein

\begin{tabular}{cccc}
\hline \multirow{2}{*}{ Uji Statistik } & \multicolumn{2}{c}{ Kategori } & \\
& KEK & Tidak & p \\
KEK & \\
\hline Mean & 69,4 & 81,35 & \\
Median & 70,7 & 82,02 & \\
Standar Deviasi & 9,8 & 10,21 & $0,001 *$ \\
Minimum & 84 & 108,9 & \\
Maksimum & 44,1 & 59,9 & \\
\hline * Uji Independent T-Test & &
\end{tabular}

Berdasarkan uji Independent T-Test didapatkan hasil $\mathrm{p}=0,000(\mathrm{p}<0,05)$ yang artinya ada perbedaan tingkat konsumsi protein pada responden KEK dan tidak KEK di SMA Negeri 1 Pasawahan. Ini sejalan dengan peneltian Petrika (2014) yang menunjukkan adanya perbedaan tingkat konsumsi protein antara kelompok KEK dan tidak KEK di Kecamatan Sedayu, Bantul. Penelitian Marlenywati (2010) pada remaja 15-19 tahun di Kota Pontianak menunjukkan bahwa konsumsi protein $<80 \%$ berpeluang 13,42 kali mengalami KEK dibandingkan dengan konsumsi energi $\geq 80 \%$.

Protein adalah komponen dasar dan utama makanan yang diperlukan oleh semua makhluk sebagai perkembangan jaringan kulit, otot, otak, sel, darah merah, rambut, dan organ tubuh lainnya yang dibangun dari protein. Ketika zat gizi yang masuk ke dalam tubuh jumlahnya kurang atau tidak adekuat, maka tubuh akan menggunakan cadangan lemak untuk memenuhi kebutuhannya dan terjadi penurunan cadangan lemak dalam tubuh. Ketika cadangan lemak habis, akan terjadi penurunan fungsional dalam jaringan hingga kerusakan jaringan dan perubahan biokimia yaitu sel-sel yang beradaptasi dan berkompensasi dengan cara menggunakan cadangan protein yang ada di hati dan otot untuk diubah menjadi energi (Aritonang, 2010).

Protein bersama karbohidrat dan lemak merupakan sumber energi bagi tubuh. Protein tersusun dari molekulmolekul yang disebut asam amino. Setiap asam amino didegradasi menjadi piruvat atau zat siklus asam sitrat dan dapat menjadi prekrusor sintesis glukosa di hepar yang disebut glikogenik atau glukoneogenik. Jika jumlah protein terus meningkat maka protein dipecah menjadi asam amino untuk dijadikan energi atau disimpan dalam bentuk lemak. Hasil pencernaannya yg berupa asam amino, digunakan untuk menyusun jaringan baru, mengganti jaringan yang rusak, membentuk hormon dan enzim, diubah menjadi lemak atau dioksidasi menjadi 
energi. Pemecahan protein jadi asam amino terjadi di hati dengan proses deaminasi atau transaminasi. Transaminasi yaitu mengubah alanin dan alfa ketoglutarat menjadi piruvat dan glutamate. Diaminasi yaitu mengubah asam amino dan NAD+ menjadi asam keto dan NH3. Jika asupan nutrisi kekurangan karbohidrat dan lemak maka mengakibatkan kurangnya asam piruvat dan oksaloasetat. Sehingga protein akan dipecah dan membantu proses glukoneogenesis untuk menghasilkan ATP tanpa meyimpan cadangan protein di hati dan otot (Burnama, 2011).

Besarnya risiko pada wanita dewasa dengan asupen protein $<80 \%$ AKG dibanding mereka yang memiliki asupan protein $>80 \%$ AKG adalah 1,163 kali lebih tinggi. Artinya jika seseorang mempunyai asupan protein rendah maka ia akan memiliki peluang lebih besar untuk menderita KEK. Hal ini sejalan dengan prinsip asupan gizi dengan status gizi pada seseorang. Jika asupan protein cukup maka status gizi akan baik termasuk ukuran lingkar lengan atas (LILA). Artinya protein sebagai sumber energi akan dilakukan sebagai kompensasi defisit energi untuk mengurangi kejadian KEK (Guyton \& Hall, 2008).

\section{KESIMPULAN}

a. Prevalensi kejadian KEK di SMA Negeri 1 Pasawahan yaitu dari total 217 siswi, didapatkan $121 \quad(55,76 \%)$ siswi termasuk kategori KEK $(<23,5$ $\mathrm{cm})$ dan $96(44,24 \%)$ siswi termasuk kategorti tidak KEK $(\geq 23,5 \mathrm{~cm})$.

b. Sebagian besar responden memiliki pengetahuan gizi prakonsepsi yang kurang yaitu sebanyak 40 responden (54\%), yang terdiri dari 24 responden KEK dan 16 responden tidak KEK.

c. Sebagian besar responden memiliki tingkat konsumsi energi yang baik yaitu sebanyak 39 responden $(52,7 \%)$, yang teridiri dari 9 responden KEK dan 30 responden tidak KEK.

d. Sebagian besar responden memiliki tingkat konsumsi protein yang kurang yaitu sebanyak 42 responden $(56,8 \%)$, yang teridiri dari 33 responden KEK dan 9 responden tidak KEK.

e. Tidak ada perbedaan pengetahuan gizi prakonsepsi antara responden KEK dan tidak KEK di SMA Negeri 1 Pasawahan $(\mathrm{p}=0,179)$.

f. Ada perbedaan tingkat konsumsi energi antara responden KEK dan tidak KEK di SMA Negeri 1 Pasawahan $(\mathrm{p}=$ 0,001).

g. Ada perbedaan tingkat konsumsi protein antara responden KEK dan tidak KEK di SMA Negeri 1 Pasawahan $(p=0,001)$.

\section{DAFTAR PUSTAKA}

Achadi., 2013, Gizi dan Kesehatan Masyarakat, Raja Grafindo, Jakarta.

Angka Kecukupan Gizi (AKG)., 2013, Jakarta.

Aritonang, E., 2010, Kebutuhan Gizi Ibu Hamil, IPB Press, Bogor.

Adhiyati E., 2013, Hubungan Pengetahuan dan Asupan Gizi Terhadap Kejadian KEK Pada Ibu Hamil di Kecamatan Terbanggi Besar Kabupaten Lampung Tengah Provinsi Lampung, Tesis, Universitas Gadjah Mada, Yogyakarta. 
Almatsier., 2003, Prinsip Dasar Ilmu Gizi, PT Gramedia Pustaka Utama, Jakarta.

Bisai S. dan Bose, K., 2008, Body Mass Index and Chronic Energy Deficiency Among Adult Tribal Populations of West Bengal. India.

Budiyono., 2002, Gizi dan Kesehatan, Bayu Media, Malang.

Burnama dan Fitra, J., 2011, Metabolisme Protein dan Asam Nukleat, Universitas Syiah Kuala, Banda Aceh.

Cetin, Berti C, Calabrase, S., 2009, Role Of Micronutrients In The Periconceptional Period, Hum Reprod Update, 16(1):80-95. doi: 10.1093/humupd/dmp025.

Departemen Gizi dan Kesehatan., 2011, Gizi dan Kesehatan Masyarakat, Raja Grafindo Persada, Jakarta.

Gardiner, PM., Nelson, L., Shellhaas, C.S., Dunlop, A.L., Long, R., Andrist, S., Jack, B.W., 2008. The Clinical Content of Preconception Care : Nutrition and Dietary Supplements, Am J Obstet Gynecol. 2008 Dec; 199(6 Suppl 2): S34556. doi: 10.1016/j.ajog.2008.10.049.

Gibson, R, S., 2005, Principle Of Nutritional and Assesment. Oxford University Press. New York.

Guyton dan Hall., 2008, Bahan Ajar Fisiologi Kedokteran, EGC, Jakarta.

Hadi, H., 2005, Beban Ganda Masalah Gizi dan Implikasinya terhadap Kebijakan Pembangunan Kesehatan Nasional, Yogyakarta.

Hamid dan Fauziyah., 2014, Analisis Faktor Risiko Kekurangan Energi Kronik (KEK) pada Wanita Prakonsepsi di Kota Makassar, Bagian Gizi Fakultas Kesehatan Masyarakat Universitas Hasanuddin, Makassar.

Irianto dan Koes., 2014, Ilmu Kesehatan Masyarakat, Alfabet, Bandung.

Kartasapoetra, G., 2005, Ilmu Gizi, Korelasi Gizi, Kesehatan dan Produktivitas Kerja, Rineka Cipta, Jakarta.

Khomsan, Ali., 2000, Pangan dan Gizi untuk Kesehatan, Rajawali Sport, Jakarta.

Marlenywati., 2010, Risiko KEK pada Ibu Hamil Remaja 15-19 Tahun di Kota Pontianak Tahun 2010, Tesis, Universitas Indonesia, Depok.

Murray, R. K., Harper's Biochemistry 25th ed. Appleton \& Lange. America 2000 : Stryer L .1995. Biochemistry 4th, page $603-623$.

Papalian dan Olds., 2001, Perkembangan pada Remaja, Rineka Cipta, Jakarta. 
Proctor, Janie., 2006, Preconception Nutrition Knowledge, Dietary Intakes And Lifestyle Characteristics Of Auckland Women, Tesis, Massey University, Albany, New Zealand.

Petrika, Hadi, Nurdiati., 2014, Tingkat Asupan Energi dan Ketersediaan Pangan Berhubungan dengan Risiko Kekurangan Energi Kronis (KEK) pada Ibu Hamil, Jurnal Gizi dan Dietetik Indonesia, Vol. 2. No 3. 140-149.

Riskesdas., 2013, Angka Kecukupan Gizi yang Dianjurkan Bagi Bangsa Indonesia. Badan Penelitian dan Perekembangan Kesehatan, Jakarta.

Santosa, T. A., 2013, Hubungan Tingkat Pengetahuan tentang Stroke dengan Perilaku Pencegahan Stroke pada Klien Hipertensi di Puskesmas Depok II Sleman Yogyakarta. Ilmu Keperawatan Respati, 3(02). http://journal.respati.ac.id/index.php/ilmukeperawatan/article/view/211

Simarmata, M., 2008, Hubungan Pola Konsumsi, Ketersediaan Pangan, Pengetahuan Gizi dan status Kesehatan dengan Kejadian KEK pada Ibu Hamil di Kabupaten Simalungun, Tesis, Pascasarjana Universitas Sumatera Utara, Medan.

Sirajuddin., 2010, Analisis Hubungan Pengeluaran, Asupan Protein dan Kejadian KEK pada Wanita Dewasa di Sulawesi selatan, Skripsi, Politeknik Kesehatan Makassar, Makassar.

Soekirman., 1999, Ilmu Gizi dan Aplikasinya untuk Keluarga dan Masyarakat, Renika Cipta, Jakarta.

Waryono., 2010, Gizi Reproduksi, Pustaka Rihama, Yogyakarta.

Weerd, S.D., Steegers, E.A.P., Heinenc, M.M., Eertweghc, S.V.D., Vehofd, R.M.E.J., Steegers-Theunissen, R.P.M., 2003, Preconception Nutritional Intake and Lifestyle Factors : First Results of an Explorative Study, Eur J Obstet Gunecol Reprod Biol 2003: 111: 167-1672.

Widyakarya Nasional Pangan dan Gizi (WNPG)., 2004, Lembaga Ilmu Pengetahuan, Jakarta. 